\title{
Stone in Cognitive Perspective
}

\author{
Mara Baghdasaryan \\ Yerevan State University
}

\begin{abstract}
This paper is aimed to look into the concept pup/stone, to reveal its meaning capacity, to illustrate its characteristics. The parallel study of the concept in four languages enables a cross-cultural perspective into the phenomenon which is essentially linguocultural. The systematization of the phraseology through cognitive models/frames designed on the basis of the idea realized by the concept and their analysis reveal the common and specific features of this concept across cultures.
\end{abstract}

Key words: concept "stone", linguocultural analysis, cognitive frame, conceptualization, lexical realization, phraseology, counterpart.

\section{Introduction}

Cross-cultural communication has become an indispensable part of our contemporary reality and the study of languages across cultures is now vital as never before. In this context our studies of languages take more various and complex forms.

But first we should understand what culture is and how it can be approached. Culture is generally defined as a system of values and beliefs, which we share with others and the whole of which gives us a sense of belonging or identity. And naturally these values and beliefs are different within various nations and societies.

We should understand what language is. It, in fact, is words and phrases that do not just have abstract meanings. They are the reflection of certain concepts and meanings that vary from culture to culture. They are symbols for social and material interconnections and can be understood in the context of communication, the latter finding its realization or specification in culture. So, 
language being part of culture can be defined as a cultural resource and also a powerful tool of human activity which, in its turn, is culture bound, too.

Hence we would consider it relevant to state, as an important standpoint for our research, the idea that any language should be considered and referred to as culturally biased. It advances the cultural assumptions and values embedded in its words, structures and philosophy.

Stone in Armenian, Russian, English and Italian: Definitions and Lexical Realizations

The concept to be analyzed in the framework of the present paper is pup/stone. It is deeply rooted in the Armenian national consciousness and culture. This concept demonstrates a wide range of meanings and a huge potential of context coverage. It is a most frequently referred concept in the Armenian linguoculture. Along with literary expressions there are also many dialectal and colloquial ones, which is another evidence showing that this concept is culture bound.

The study of the mentioned concept will be realized through a comparative analysis with other linguocultures - English, Russian and Italian - as things often become more obvious in comparison. So the linguocultural characteristics of the concept stone will be revealed and interpreted in its corresponding realizations in a number of languages. Such a comparative study of language realizations will help to reveal and understand the mental and cultural characteristics of thinking and behavior valid in different cultures, identify the common features and differences of worldview and world perception. The analysis of linguocultural concepts illustrates their conceptual, evaluative role and function and enhances a better understanding of the cultures. The abovementioned concept will be presented through mental models/frames aimed at revealing the linguocultural thinking. ${ }^{1}$

In the present paper the concept pup/stone will be discussed through a number of cognitive frames which have been designed on the basis of the meanings realized by it. Before presenting the frames proper it is regarded relevant to look into the definition of this noun given in explanatory 
dictionaries. The lexical-semantic field of the meaning of this noun has both similarities and differences in the languages being discussed (the presentation of the specifically professional or technical meanings of this noun are omitted here as non-relevant to this research).

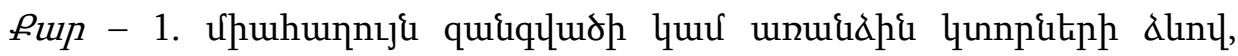

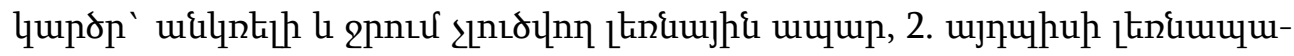

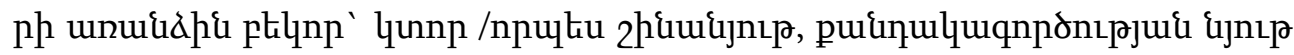

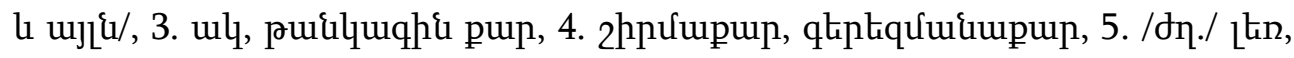

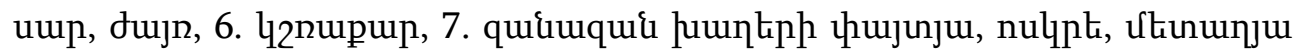
lu uJL hnpphl hptphg' \$hqnıpitiphg jnıpupuisjnıpn (Aghayan1976:1557):

Камень - твердая горная порода кусками или сплошной массой, а также кусок, обломок такой породы (Ожегов 1988:214).

Stone - 1. hard solid non-metallic mineral matter of which rock is made, especially as a building material; a small piece of rock found on the ground; a meteorite made of rock, as opposed to metal; 2. a piece of stone shaped for a purpose, especially one of commemoration, ceremony, or demarcation/ a memorial stone/ boundary stones; a gem or jewel; a round piece or counter, originally made of stone, used in various board games, especially the Japanese game of go; 3. a hard seed in a cherry, plum, peach, and some other fruits (Oxford Dictionary 2010).

Pietra - 1. frantume di roccia, usato come materiale da costruzione o per ornamento (Zingarelli 2014:1677).

As is evident from the dictionary definition the first meanings are principally the same which refer to stone as a solid mineral matter. In the second place in the Armenian dictionary comes the presentation of stone as a building material and what is of particular interest also material for sculpture or some other creation. It is remarkable that almost the same is the basic definition 
of stone in the Italian dictionary: a building material or a material for ornament. This indicates that the ideas of creation and aesthetics are of utmost importance in the Italian culture. In the Russian explanatory dictionary no further specification of stone is given. Then in the Armenian and English definitions references to the precious stone and memorial come similarly. Afterwards another point of similarity is observed in the meaning of different objects used in board games.

Now let us look into the differences. In the Armenian version of stone there are also meanings of a stone used in weighing and a mountain/rock. The latter meaning is recorded in the colloquial speech and is of particular interest as here the noun stone is actually used in the widest sense referring to any stone mass of big size. In the English dictionary another meaning of stone is recorded -a hard seed in fruit. Obviously it is a narrow specific meaning and does not have such a powerful generalizing coverage as the Armenian stone in the sense of any rock or mountain.

So, in the explanatory dictionary we can already observe two important linguocultural characteristics of stone in Armenian: it is of the widest universal meaning as a reference to any piece or aggregation of this mineral and a particular meaning as a source of creation for this nation.

This is only a preliminary observation of the concept stone, which will further be elaborated in the study of the phraseological units with it. The reference to phraseology is considered most useful in the framework of this research as phraseological units are virtual condensations of language which reflects national thinking, lifestyle, culture - in a word the national picture of the world.

\section{Stone in Phraseology and through Cognitive Frames}

According to the phraseological dictionaries used for the collection of the data (Sukiasyan, Galstyan 1975, Voynova, Zhukov, Molotkov, Fyodorov 1986, Oxford Dictionary of Idioms 2004, Zingarelli 2014) there are around 95 phraseological units with the concept stone in the Armenian language, around 25 in the Russian language, around 15 in the English language and around 50 in 
the Italian language. The lexical realizations of the concept stone are pup, $L^{\mathrm{k} n}$, uup in Armenian, камень, гора in Russian, stone, mountain, rock in English and pietra, roccia, sasso, montagna, monte in Italian. Even at the only sight of these figures it becomes evident that Armenian is particularly rich in the phrases with the concept stone. Another marker showing that stone is typical of the Armenian linguoculture is that around 10 cognitive frames have been designed on the basis of the Armenian phraseological units. Some of these frames are further made precise through subframes. All this indicates the depth and variety of the use of the concept stone in Armenian. Some of these frames are valid in Russian, English and Italian, too, but surely not in such an impressive representation. Also there are some frames which are not typical of Armenian but have been designed on the basis of the data of the Russian, English and/or Italian languages.

Thus below will be presented the frames designed as a result of our research (the order of the frames is solely conditioned by the order of the occurrence of the corresponding Armenian phraseological units in the dictionary and has a simply technical reason).

1. stone - coldness; emotionlessness; indifference; immobility

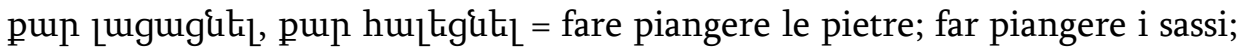
fare pena/ compassione ai sassi; fare ridere le pietre; cuore di pietra $=$ avere un cuore di sasso; essere un sasso; essere duro come un sasso, essere di sasso $\neq$ non essere di sasso;

pup uiqunupptennıpjnı\{; fall on stony ground /of words or a suggestion/;

pup lunpt $\mathrm{L}=$ rimanere di pietra; rimanere di sasso

2. stone - failure, prevention, obstacle

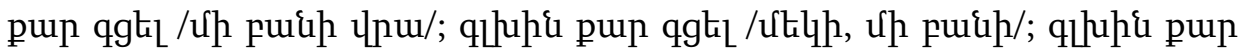

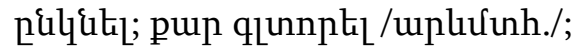

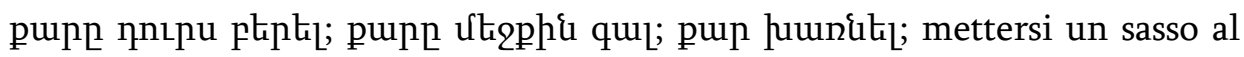
collo; gettare il sasso e nascondere il mano

2.1 closing - silencing 


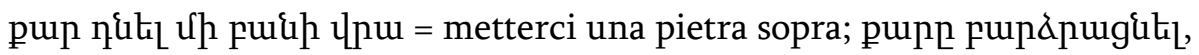

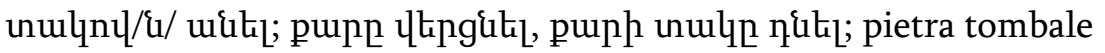

2.2 end of good/success

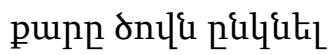

2.3 collapse (also moral)

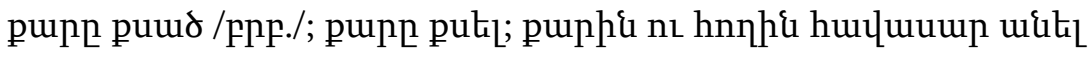

3. stone - solidity/firmness, strength, powerfulness

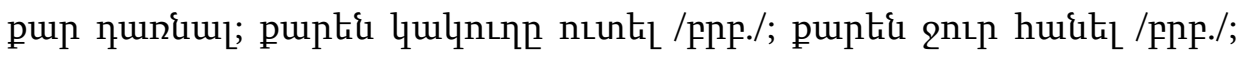

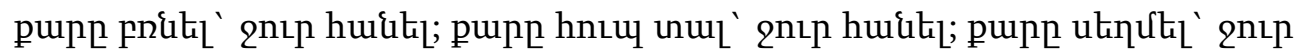

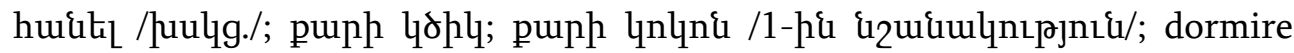
come un sasso; dormire come una monatgna; pup thip' qưupup; thnuil ultu luiqqil $\mathrm{L}_{\mathrm{L}}=$ стоять горой за кого, за что; стать /встать/ горой за кого, за что; как на каменную гору/стену надеяться/полагаться на кого, на что; как за каменной стеной; avere la roccia tra le ditta

\section{1 bigness/big measurement}

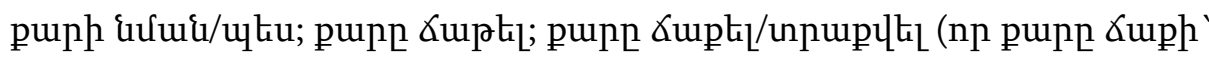

unuplh); cavare sangue da una pietra; spaccare I sassi; puph ไpu nifi-

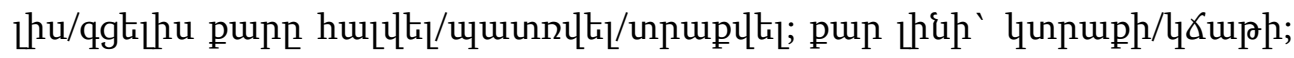

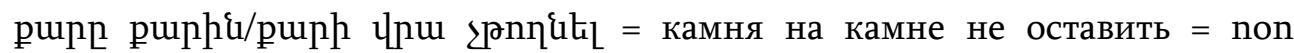

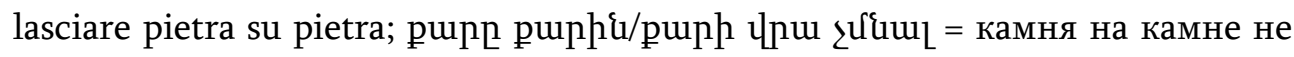

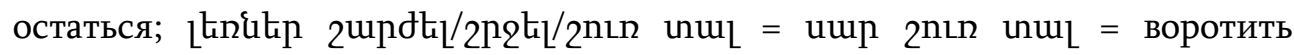
горы/гору; ворочать/двигать горами $=$ move mountains $=$ muovere $/$ smuovere mari e monti, золотые/златые горы, идти/пойти в гору/вверх ₹ идти/пойти под гору/под уклон; ltanp/thplutig/unıl ditg = la montagna ha partorito il topolino; promettere mari e monti; make a mountain out of a molehill; uuph qufuq/ultu = essere grande come un amontagna; sembrare una montagna; uu-

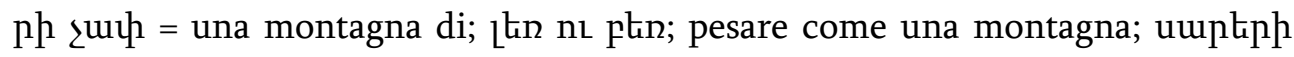

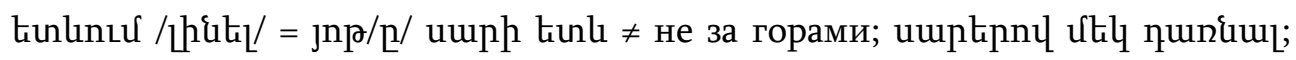




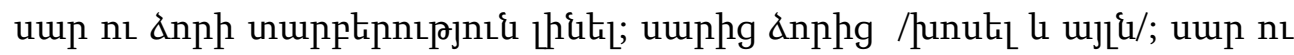

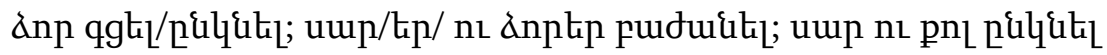

\section{2 stubbornness}

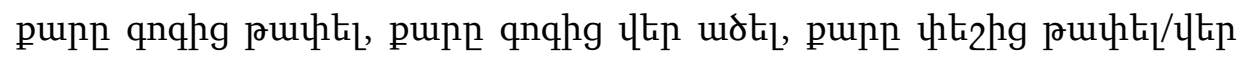
urblil /huulg./

\section{3 burden, difficulty}

uup pilfikin nutiphg = как гора с плеч /свалилась/; upunh Џpujhg duip pup ndqutl/upung pup piliqt $=$ камень с души/с сердца свалился $\neq$ камень на душе;

have a mountain to climb;

uuph uuph lnu nitit;

avere una pietra sullo stomaco;

pupn qluhi unul, qlnı hup puphq;

leave no stone unturned

3.4 stinginess/the quality of being tight-fisted

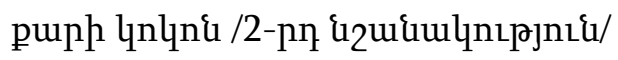

4. stone - hardship/difficulty, torturing/suffering

kplynı puph upuipnıu = between a rock and a hard place /informal/;

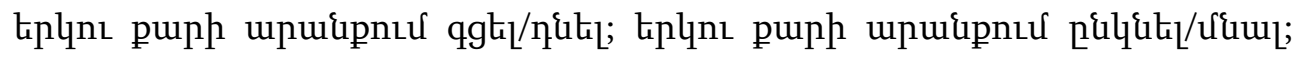

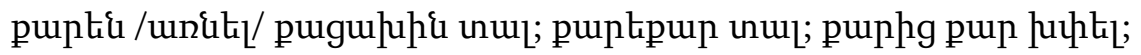

нашла коса на камень; подводные камни/камешки; камень преткновения /книжн./= on the rocks /of a relationship or enterprise/

4.1 wondering from one place/side to another (as a type of suffering, hardship)

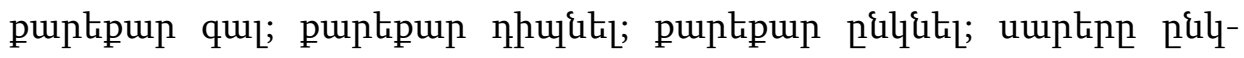

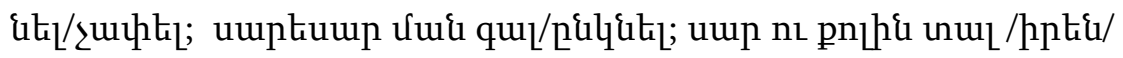


5. stone - creation (also by the power of mind; with difficulties/overcoming hardships), basis - generation

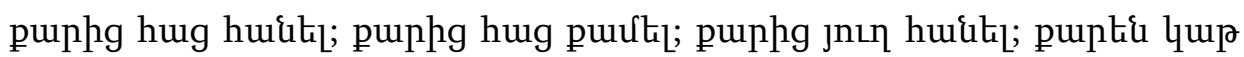

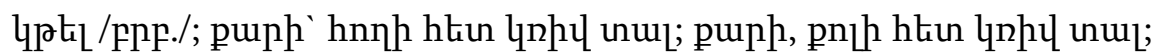

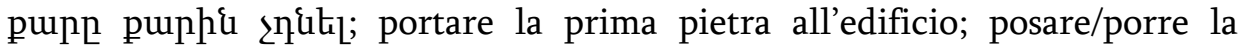
prima pietra; краеугольный камень = pietra angolare; pietra dello scandalo

6. stone - silence

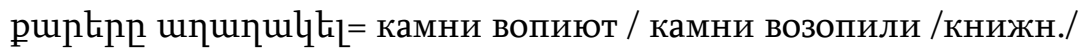

7. stone-hint; meaning

pup qgil utilh puiqupuingp = бросать $/$ кидать $/$ пускать камешки/камень в огород; pupp qunnıpp qgŁi ;

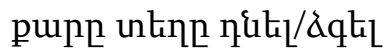

8. stone - means

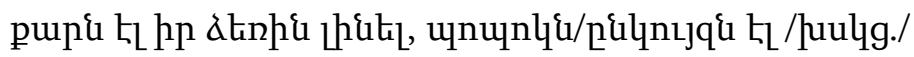

9. stone - wilderness - withdrawal from people/solitude; withdrawal from people/from civilization

uupn puzltil; uuph ung

10. stone - memorial

pup qghl

11. stone-criticism

забросать/закидать камнями/грязью, бросить камнем /в кого/;

cast $/$ throw the first stone $=$ scagliare la prima pietra

12. stone - danger - suffering

держать/иметь камень за пазухой; lanciare un sasso nello stagno; tirare/gettare sassi in piccionaia/colombaia 


\section{3. stone - challenge - difficulty \\ пробный камень = pietra di paragone}

The above presented system of frames has mainly been designed on the basis of the Armenian phraseology: ten frames out of thirteen. The last three frames and also subframe 3.5 have been designed on the basis of the English, Russian and/or Italian phraseological units though, for example, frames 12 and 13 have some shades of meaning common with frame 4.

The Armenian lexical realization $j^{t} n$ and its Russian counterpart ropa, English counterpart mountain, Italian counterparts montagna and monte are expressed in the general frame 3 and the subframe 3.1. Another fact we would like to comment on is that the two other lexical realizations of the concept stone in Armenian - Zlin and uup - are less representative than the word pup which is actually the basic linguistic embodiment of the concept. In the case of $l^{k} n$ and its counterparts the idea of firmness becomes even stronger as in lthulu ulu huqquli, стоять горой за кого/что, стать/встать горой за кого/что, как на каменную гору надеяться/полагаться на кого/что and the idea of bigness associated with physical size becomes more remarkable, also particularly as a result of the use of lin in plural as in linilip 2updtl, воротить горы/ гору, двигать горами, move mountains, muovere mari e monti, золотые горы, promettere mari e monti and the juxtaposition of the ideas of bigness and smallness as in linz /tipliktg/ Unzl dikg, la montagna ha partorito il topolino, promettere mari e monti, make a mountain out of a molehill, muovere mari e monti.

The Armenian lexical realization uup and its counterparts in the other languages (which are practically the same as those of $l$ thn) are mainly expressed in the subframes $3.1,3.3$ and 4.1. In the case of subframe 3.3, too, uup is conceptually stronger than pup and makes the idea of burden/difficulty stronger: compare upung pup pilikitl and uup pillikl nuukphg. Another technique of pluralization of idea - repetition of the word-concept - is used in uupp uuph lpu nilil expressed through the same frame. Anyway, the conceptualization through uup is obviously frequent through its idea of big 
measurement, physical bigness in particular: uuph \&ufuk/ultu, essere grande come una montagna, sembrare una montagna, uuph ¿uนh, una montagna di, uup $2^{n}$ nn unul. Here, too, the ideas of plurality and contrast are exploited to make the bigness of measurement more expressive, e.g. uupleph tunlnut

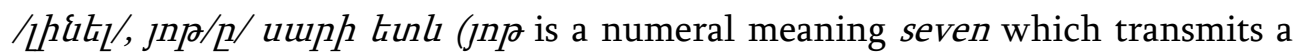
much stronger idea of plurality than the plural of the corresponding noun

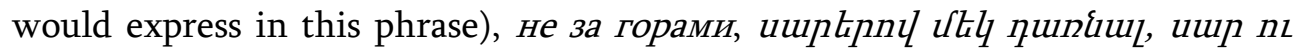

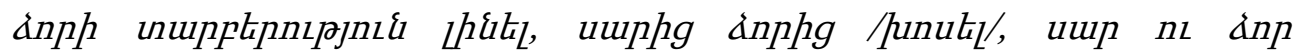

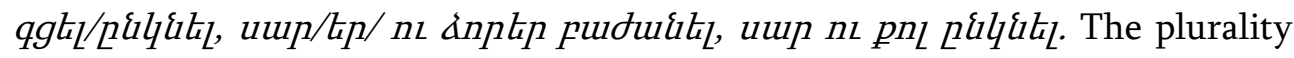
of uup suggests the idea of a bigger coverage in particular. With reference to the subframe 4.1 it should be stated that apart from the idea of wondering from one place/side to another as a type of suffering or hardship as in puplipup qul,

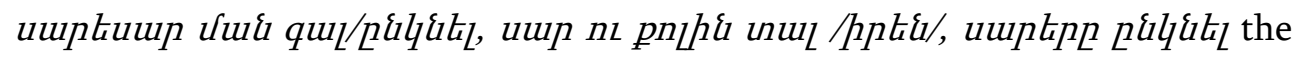
phraseological units with uup/tip/ and umpluuup also express the idea of a difficult search.

Frame 9 is actually designed on the basis of the phraseological units with uup. Wilderness expresses the idea of being distanced from people either in the meaning of seclusion, solitude or in the meaning of lacking civilization and being ignorant/harsh: compare uupL puzllil and uuph upg.

Frame 11 expresses the idea of criticism exemplified through забрасывать/забросать камнями кого, бросать/бросить камнем в кого in Russian and cast/throw the first stone in English and scagliare la prima pietra in Italian. It should be mentioned that in English and Italian it is the same phrase which comes from St John's Gospel and is universal.

Frames 12 and 13 are exemplified through the Russian and/or Italian phrases держать/иметь камень за пазухой аnd пробный камень / pietra di paragone, correspondingly. The ideas of danger - suffering and challenge - difficulty as can be seen have something in common with frame 4 but still the main conceptual contents is expressed in the ideas of danger and challenge.

It is remarkable that there are many synonyms and even antonyms among the phraseological units with the concept stone. Below are only presented some 
of them to avoid an extensive repetition (the sequence of these examples is according to the conceptual classification above):

pup uugugit $_{L}=$ pup hul pugit $_{[}$;

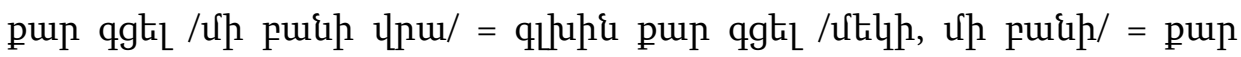
qlunnptis/upliưnh./;

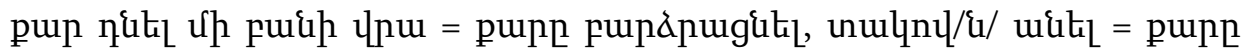
¿thofitil, puph unulp nititi;

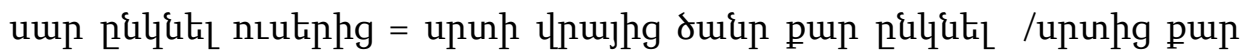
nqulqutil;

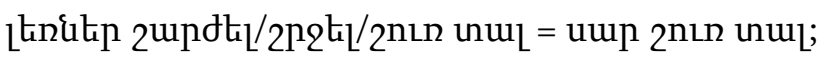

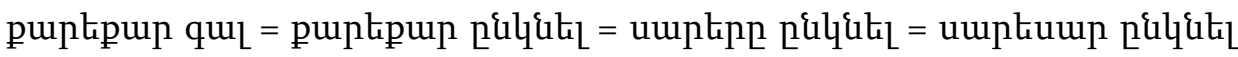

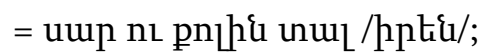

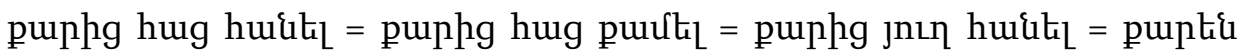

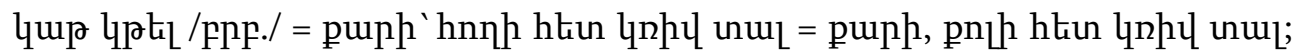
fare piangere le pietre $=$ far piangere i sassi;

essere duro come un sasso $=$ essere di sasso $\neq$ non essere di sasso;

rimanere di pietra = rimanere di sasso;

dormire come un sasso = dormire come una monatgna;

воротить горы/гору = ворочать/двигать горами;

идти/пойти в гору /вверх/ f идти/пойти под гору/под уклон;

забросать/закидать камнями/грязью = бросить камнем /в кого/.

\section{Conclusion}

The active use of the concept stone in phraseology of different languages and even the existence of synonymous and antonymous phraseological units among them account for the fact that the stone is one of the most basic living environments common for all human beings. At the same time the particular abundance of the phraseological units with the concept stone and the variety of the conceptualization of the underlying notion, as well as the noticeable synonymic series in Armenian are strong indicators that this concept has a special meaning for this nation. The stone has for centuries been the typical living environment of the Armenian nation, it has become an essential scope of 
worldview, a vital means of struggle for life, a basic source of creation - both material and spiritual - for this people. Stone is specific to the Armenian nation, it is deeply rooted and active in its language. The natural environment is "fixed" in the culture and language - the big repositories and sources of thinking and behaviour.

Note:

1. A frame can be defined as a structure of knowledge or a mechanism of knowledge building: in the broad sense, a frame is a cognitive model. A frame is a unified structure of knowledge, a coherent schematization of experience. It is a structure of data which exists in a person's consciousness and which a person uses to recognize and process typical situations and phenomena. It represents the essential, typical and possible features of the concept, which can be conditioned to this or that extent, that is they have a situational basis. Frames shape a person's perception of the world and direct his behaviour (See Kubryakova, Demyankov, Pankrats, Luzina 1997, Minskiy 1979, Fillmore 1988).

\section{References:}

1. Aghayan, E. (1976) Ardi hayereni batsatrakan bararan. Yerevan: "Hayastan" hratarakchutyun.

2. Sukiasyan, A.; Galstyan, S. (1975) Hayots lezvi dardzvatzabanakan bararan. Yerevan: Yerevani hamalsarani hratarakchutyun.

3. Voynova, L.; Zhukov, V.; Molotkov, A.; Fyodorov, A. (1986) Frazeologicheskiy slovar' russkogo yazika. / Pod red. A. Molotkova, Izd. 4oye. M.: Russkiy yazik.

4. Kubryakova, Ye.; Demyankov, V.; Pankrats, Yu.; Luzina, L. (1997) Kratkiy slovar' kognitivnikh terminov. M.: MGU. 
5. Minskiy, M. (1979) Freymi dlya predstavleniya znaniy. M.: Energiya.

6. Ozhegov, S. (1988) Slovar' russkogo yazika. 20-oye izd. M.: Russkiy yazik.

7. Fillmore, Ch. (1988) Freymi i semantika ponimaniya. // Novoye v zarubezhnoy lingvistike. Kognitivniye aspekti yazika. Vip. XXIII. M.: Progress.

8. (2010) Oxford Dictionary (for ABBYY Lingvo x5). $3^{\text {rd }}$ edition. Oxford: OUP.

9. (2004) Oxford Dictionary of Idioms. / Ed. by Judith Siefring. $2^{\text {nd }}$ edition. Oxford, New York: OUP.

10. Zingarelli, N. (2014) Vocabolario della Lingua Italiana. Milano: Zanichelli.

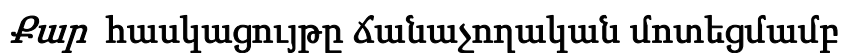

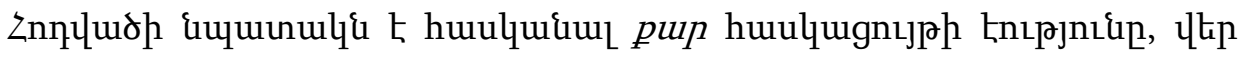

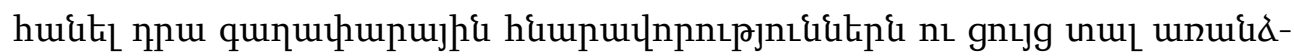

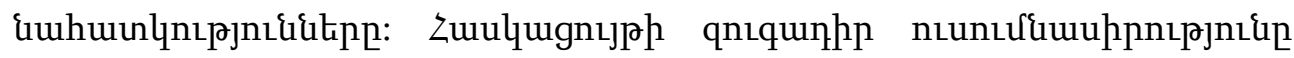

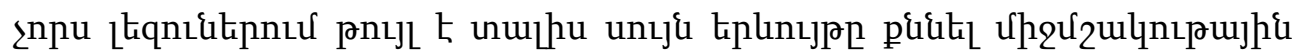

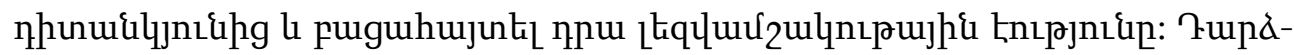

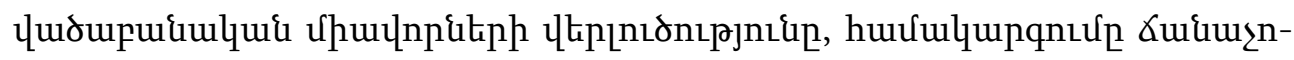

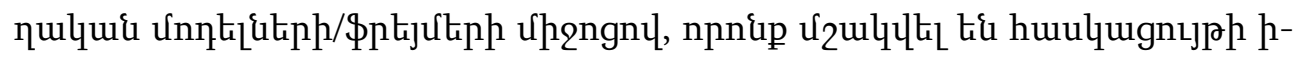

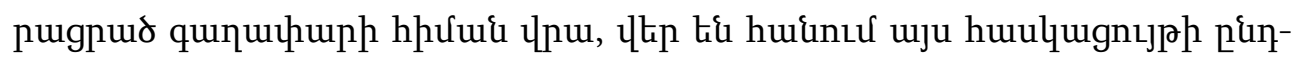

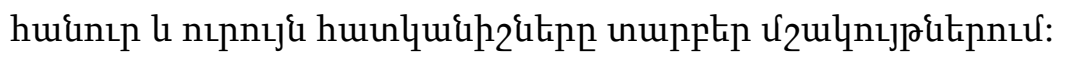

